УДК 621.438

\title{
ПІДВИЩЕННЯ ЕФЕКТИВНОСТІ ТЕПЛОУТИЛІЗАЦІЙНИХ ЕНЕРГОУСТАНОВОК НА НИЗЬКОКИПЛЯЧИХ РОБОЧИХ ТІЛАХ НА ЗМІННИХ РЕЖИМАХ ЇХ РОБОТИ
}

\section{Сергіснко P.B.}

Інститут технічної теплофізики НАН Украӥни, вул. Желябова, 2, а, Київ, 03680, Україна

В роботі розглянуто і вирішено науково-прикладні питання вибору робочого діапазону теплоутилізаційної енергоустановки (ТУЕУ), розроблення способів підвищення ефективності роботи установки на змінних режимах $\mathrm{i}$ при зміні атмосферних умов. Вдосконалено методику і програму термодинамічного і теплового розрахунку ТУЕУ в умовах обмеженої потужності джерела теплоти за обраним тепловим перепадом.
В работе рассмотрены и решены научно-прикладные вопросы выбора рабочего диапазона теплоутилизационной энергоустановки, разработки способов повышения эффективности работы установки на переменных режимах и при изменении атмосферных условий. Усовершенствована методика термодинамического и теплового расчета ТУЕУ в условиях ограниченной мощности источника теплоты по выбранному перепаду.
Important scientific and applied issues of selecting the operating range of heat utilized power plant (HUPP), development of ways to increase the efficiency of the plant under variable modes and changing atmospheric conditions are discussed and solved in the paper. Methods and program of thermodynamic and thermal calculation of HUPP in conditions of limited power heat source for the selected thermal difference are improved.

Библ. 7 , рис. 4.

Ключові слова: теплоутилізаційна енергоустановка, газотурбінна установка, утилізація теплоти, термодинамічний цикл, низькокипляче робоче тіло.

\section{Bcmyn}

Значний тепловий потенціал, що міститься у вихлопних газах газотурбінних установок (ГТУ), є ідеальною основою для використання ГТУ в енергетичних цілях, що підтверджують численні випадки проектування та експлуатації нових парогазових установок (ПГУ) в корисних для електроенергетики цілях. На сьогодні певний обгрунтований інтерес становить використання парових турбін, де як робоче тіло використовуються органічні теплоносії 3 низькою температурою кипіння i низькою теплотою пароутворення. В той час як температурні межі водяних ПГУ починаються 3 $350 \ldots 400{ }^{\circ} \mathrm{C}$, органічні рідини здатні відбирати тепловий потенціал від джерела скидної теплоти від $60{ }^{\circ} \mathrm{C}$. Застосування НРТ дає можливість використання скидної теплоти для виробництва механічної чи електричної енергії, що відкриває широкі перспективи у використанні таких циклів на ТЕС, ТЕЦ та у промисловості. Використання технологій енергетичної утилізації скидної теплоти 3 використанням низькокиплячих робочих тіл (НРТ) хоча і має меншу термодинамічну ефективність, проте володіючи певними технологічними перевагами, дозволяє отримати в ТУЕУ на базі ГТУ значну електричну або механічну потужність, разом 3 тим зменшуючи теплове забруднення атмосфери i поглинаючи при цьому шуми вихлопу ГТУ. Застосування НРТ має ще й експлуатаційні переваги, серед яких - технологічна відсутність води та повна автоматизація процесу. Досвід інших країн підтверджує перспективність використання ТУЕУ на ГТС та можливість їх застосування у промисловій теплоенергетиці [1-4]. Слід відзначити, що першим у розвитку і популяризації використання ТУЕУ на НРТ в Україні та країнах СНД був Інститут технічної теплофізики НАН України, згодом Московський енергетичний інститут, що працював над проектами установок для ТЕС і ТЕЦ.

Проте приводна ГТУ компресорної станції $\epsilon$ складною установкою, на режим роботи якої впливають перш за все витрата газу, що компримується нагнітачем, і температура навколишнього середовища. Внаслідок нестаціонарної витрати газу в МГ потужність ГТУ також не є 
стаціонарною. Через вплив цих факторів ГТУ працює на постійно змінних режимах роботи. При зменшенні iï потужності зменшується як температура, так і витрата продуктів згоряння, що $\epsilon$ тепловим джерелом для котла-утилізатора, внаслідок чого зменшується теплова потужність низькокиплячого контуру i, відповідно, вироблення електроенергії в ТУЕУ.

Метою даної роботи $є$ дослідження робочих характеристик ТУЕУ в умовах експлуатації на змінних режимах роботи базової ГТУ, вдосконалення підходів і методів розрахунку ТУЕУ на НРТ та розробка способів і схем обладнання для підвищення ефективності роботи установок на цих режимах.

Враховуючи пріоритетність вимог ГТС до енергетичного обладнання - надійність, пов'язана 3 простотою конструкції і експлуатації, безпека роботи і лише аж потім економіка, а також те, що на КС ГТС можливості реалізації електроенергії і теплоти, які виробляються додатково, як правило, обмежені і знаходяться практично на рівні власних потреб КС, перспективніше виглядають однокаскадні ТУЕУ.
Існують різноманітні підходи до вибору початкової температури силового циклу Ренкіна на НРТ. 3 міркувань безпеки роботи установки, а саме пожежовибухобезпечності, нами обрано температури дещо нижчі за температуру самозапалення робочих тіл, що дозволяє уникнути запалювання в К-У при виникненні витоку в ньому.

Обмеження використання безводних технологій зумовлено високими температурами вихлопних газів ГТУ, адже значним недоліком такої установки є вибухонебезпечність робочих тіл. Наприклад, для пентану температура самозаймання становить $281{ }^{\circ} \mathrm{C}$, а температури вихлопних газів ГТУ простого циклу знаходяться в діапазоні $450 \ldots 550{ }^{\circ} \mathrm{C}$ залежно від типу ГТУ. Для того, щоб температура НРТ не перевищувала температуру стабільного існування речовини, пропонується попереднє охолодження відпрацьованих газів після газової турбіни за рахунок підмішування атмосферного повітря, що дасть можливість реалізувати робочий цикл ТУЕУ та розширити діапазон роботи низькокиплячого контуру (рис. 1).

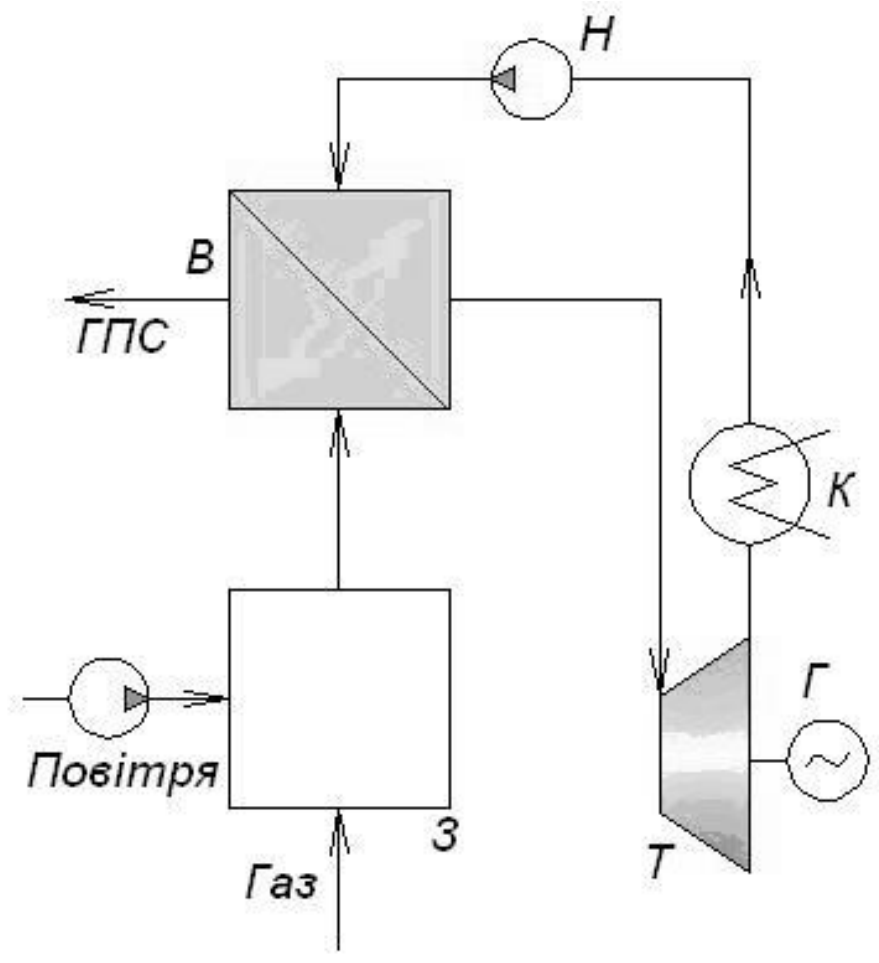

Рис. 1. Принципова теплова схема одноконтурної ТУЕУ на НРТ:

T- турбіна, Г- генератор, К-повітряний конденсатор, $\mathrm{H}$ - насос, В - випарник НРТ, 3 - змішувач повітря з газами, П- повітряний вентилятор, ГПС-газоповітряна суміш. 
Проектування ГТУ здійснюється за наступних умов: атмосферного тиску $\mathrm{p}_{\text {атм }}=101,3$ кПа, температури повітря $\mathrm{t}_{\text {пов }}=+15^{\circ} \mathrm{C}$. Але температура навколишнього середовища протягом року експлуатації змінюється в широкому діапазоні, а однією з особливостей ГТУ є значна чуттєвість iї характеристик до змін параметрів зовнішнього повітря. Так, збільшення температури навколишнього середовища на $10{ }^{\circ} \mathrm{C}$ призводить до падіння потужності ГТУ на 8..9 \%, при цьому ККД

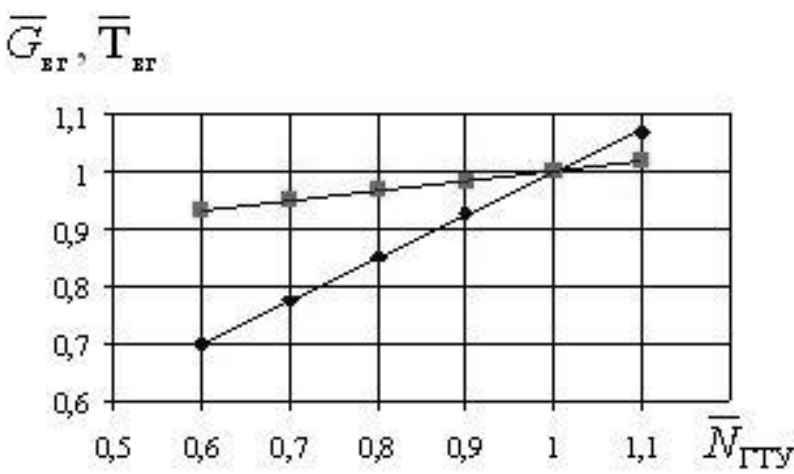

Рис. 2. Вплив температури і режиму роботи ГТУ на ї̈ характеристики.

а) відносна залежність температури вихлопних газів та їх витрати від потуюсності ГТУ: - витрата вихлопних газів; - ̈̈х температура;

Підмішування повітря дозволить значно збільшити витрати гарячого теплоносія, що підвищить ефективність роботи ТУЕУ. Регулюючи витрати повітря, можна автоматично підтримувати температуру теплоносія, що поступає в утилізаційну установку, на потрібному рівні і забезпечити таким чином ефективну $\mathrm{i}$ безаварійну роботу установки.

Для підтримання номінальної потужності ТУЕУ необхідно стабілізувати початкову температуру суміші вихлопних газів і повітря. Залежно від умов експлуатації ПГУ можуть працювати в широкому діапазоні навантажень: середнє навантаження на ГПА протягом року становить $0,7 \ldots 0,9$ номінального, а кількість газу, що перекачується, практично не змінюється сезонно. В той же час добові навантаження на ГТС змінюються на $10 \ldots 15 \%$, коефіцієнт

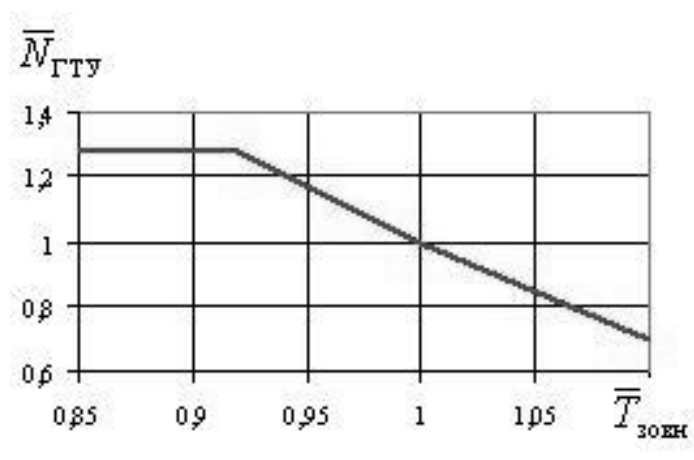

установки зменшується в абсолютних величинах на $0,825 \ldots 1,025 \%$.

Постає задача забезпечення таких робочих температур гарячого теплоносія, які були б нижче за температуру самозаймання НРТ, зберігаючи при цьому рівень та стабільність ïх питомої роботи в установці близьким до максимального $[5,6]$. Також слід враховувати залежність параметрів самої енергоустановки від зовнішніх умов та іiї навантаження (рис. 2).

б) відносна залежність потужності ГТУ від температури повітря на вході у компресор (nри $\left.t_{\text {зови }}=15^{\circ} \mathrm{C}\right)$.

нерівномірності навантаження (відношення дійсної потужності до проектної) становить 0,95. Режими часткових навантажень виникають через зміну потужності, що виробляє ГТУ. Адже при роботі ГТУ зі змінною частотою обертів, що характерно установкам для приводу нагнітача, режим роботи ГТУ визначається характеристикою споживача потужності.

3 температурою на виході та витратою вихлопних газів ГТУ безпосередньо пов'язана ефективність використання паросилового циклу в ТУЕУ. При роботі ГТУ на часткових режимах відбувається загальне зниження параметрів та характеристик двигуна, що значно впливає на ефективність реалізації циклу Ренкіна на НРТ, тому постає задача отримання його найбільш прийнятних ККД і питомої роботи. Також варто з'ясувати, як впливає температура зовнішнього 
повітря на характеристики пентанової турбіни, дослідити вплив витрат повітря і вихлопних газів та температури суміші на роботу низькокиплячого контуру. Спрощено зображені у відносному вигляді характеристики на рис. 2 є близькими для всього ряду потужностей ГТУ. Тобто основними факторами, які впливають на роботу ТУЕУ, є режим роботи ГТУ та параметри зовнішнього середовища $[5,6]$.

Поставлене завдання вирішується тим, що у комбіновану енергетичну установку додатково встановлюються дві незалежні одна від одної системи: оснащений системою частотного регулювання вентилятор повітря, що зв'язаний 3 системою регулювання ГТУ, і регулятор витрати компримованого газу для підігрівача конденсату, також зв’язаний з системою регулювання ГТУ.

Змішувач вихлопних газів 3 повітрям мож- на розглядати як своєрідний теплоперетворювач, роль якого полягає у збереженні загального теплового потенціалу гарячого теплоносія (вихлопних газів) та переведенні цього потенціалу в еквівалентний більш низький потенціал менш нагрітого теплоносія - суміші вихлопних газів 3 повітрям.

Низькокиплячий контур замкнений, витрата пентану $є$ сталою, а оскільки теплоємності НРТ і вихлопних газів для даних рівнів температур відрізняються на 4...5 \%, то для вироблення енергії можна було б використовувати лише половину теплового потенціалу вихлопних газів. Звичайно, можна було б поставити ще одну таку ТУЕУ або збільшити потужність даної вдвічі, але при цьому порушується умова, при якій температура суміші не може перевищувати температуру самозапалення НРТ (рис. 3).

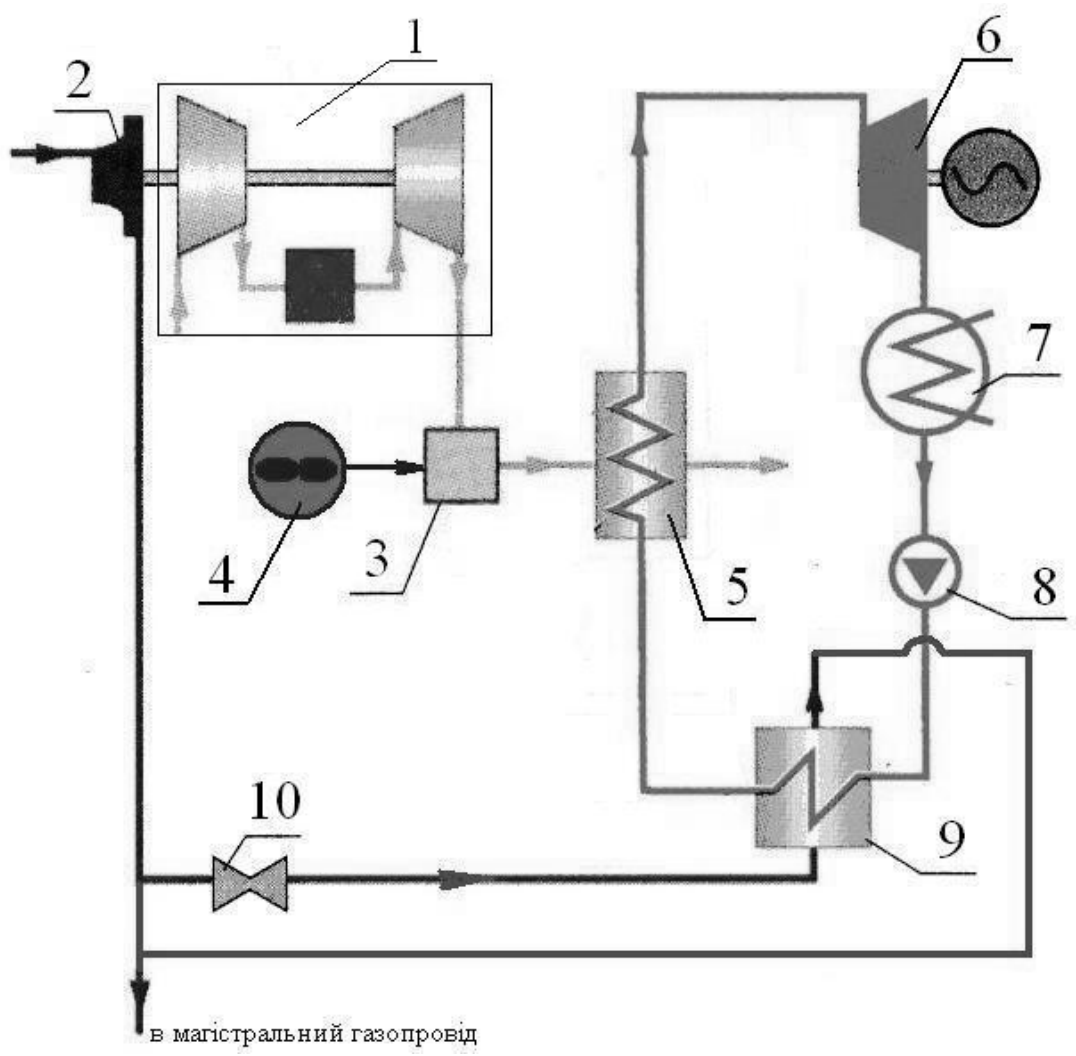

Рис. 3. Схема комплексної ТУЕУ на базі ГТУ простого циклу:

1 -ГТУ; 2 - нагнітач природного газу; 3 - змішувач продуктів згоряння ГТУ з повітрям;

4 - вентилятор повітря 3 частотною системою регулювання; 5 - котел-утилізатор;

6- турбогенератор; 7 - конденсатор; 8-конденсатний насос; 9 - підігрівач конденсату; 10 - регулятор витрати компримованого газу. 
Запропонована для ГТС комбінована енергетична установка працює наступним чином: ГТУ (1) виробляє механічну енергію, яка використовується для приводу нагнітача газу (2). Продукти згоряння газової турбіни спрямовують до змішувача (3) з повітрям, яке подається вентилятором 3 частотною системою регулювання (4) для зменшення температури продуктів згоряння до пожежобезпечного рівня. Систему подачі повітря зв'язано з системою регулювання ГТУ. Одержана суміш як нагрівальний агент поступає до котла-утилізатора (5). Далі пара поступає у турбогенератор (6) для вироблення електроенергії. Відпрацьована пара 3 турбіни поступає в конденсатор (7), а конденсат спрямовують в підігрівач (9), куди як нагрівальний агент поступає відібраний компримований газ.

Підігрітий конденсат спрямовують в котелутилізатор, а охолоджений компримований газ, змішуючи з основним потоком, спрямовують у магістральний газопровід. Це знижує температуру газу, що перекачується, та підвищує пропускну здатність газопроводу.

Зв'язок автономних вентилятора повітря i регулятора витрат компримованого газу чисто тепловий. Зв'язаний зі змішувачем вентилятор повітря з частотною системою регулювання та регулятор витрати стисненого газу для підігрівача конденсату є необхідними для стабілізації максимальної циклової температури НРТ залежно від температури та витрати продуктів згоряння з ГТУ, перший - шляхом регулювання подачі в змішувач охолоджуючого повітря, другий шляхом регулювання подачі в підігрівач конденсату компримованого газу після нагнітача. Робота встановлених змішувача і підігрівача конденсату корелюється.

Комплексна ТУЕУ відрізняється від простої енергоустановки наявністю в контурі теплообмінника для утилізації теплоти стисненого газу. При заданих витратах природного газу на КС і сталій витраті НРТ охолодження природного газу може збільшити продуктивність газоперекачування на понад $5 \%$.

Пріоритетне значення і перспективність використання такої системи регулювання параметрів ТУЕУ підтверджено патентом на корисну модель [7].
В роботі проведено повний тепловий розрахунок параметрів утилізаційної установки на пентані ТУЕУ 3 регульованим i нерегульованим підмішуванням повітря. Робоча температура 483 К. Як ГТУ обрано ДН-70, що використовується на ГТС України $\left(\mathrm{N}_{\text {Гту }}=\right.$ $=10$ МВт; $\left.\mathrm{G}_{\mathrm{вг}}=34,9 \mathrm{\kappa г} / \mathrm{c} ; \mathrm{t}_{\mathrm{вг}}=768 \mathrm{~K}\right)$.

Варто зауважити, що обравши робочу температуру низькокиплячого контуру на рівні $210{ }^{\circ} \mathrm{C}$, розрахунки проводилися лише для виробництва електроенергії на забезпечення власних потреб однієї КС, тому тепловий скидний потенціал приводних ГТУ використано не повністю. Впровадження описаної установки дозволить значно скоротити або і взагалі відмовитись від споживання дорогої електроенергії 3 мережі на власні потреби КС та для систем охолодження компримованого газу, що значно підвищує рентабельність газоперекачування.

При умовах роботи ГТУ на часткових режимах потужність пентанової турбіни зменшується на 24,5 \% (при зменшенні потужності базової ГТУ з номінальної до 0,8 номінального значення). При режимі нижче за 0,8 номінального, i при сталій витраті повітря через змішувач реалізація циклу Ренкіна стає неможливою, адже не виконується раніше закладена умова, за якою різниця між гарячим середовищем та середовищем, що нагрівається, становить не менше заданого (8 K).

При регульованій подачі повітря тенденція зменшення потужності пентанової турбіни при умовах роботи ГТУ на часткових режимах зберігається. При зменшенні потужності базової ГТУ 3 номінальної до 0,6 номінального режиму потужність пентанової турбіни зменшується на $37,7 \%$. Порівняно 3 варіантом за відсутності регулятора, витримування температури суміші на вході в К-У сталою дає до 8 \% приросту потужності турбіни. Тобто динаміка відносного падіння потужності турбіни низькокиплячого контуру при витримуванні максимально можливої температури на вході в К-У менша, ніж при відсутності системи регулювання подачі повітря. Не менш важливим $є$ те, що стабілізація температури розширює експлуатаційний діапазон роботи пентанової турбіни, де виконується закладена умова, вдвічі. 
Відносна частка ефективної електричної потужності ТУЕУ за рахунок використання теплоти компримованого газу в діапазоні температур пентану на виході з теплообмінника $50 \ldots 60{ }^{\circ} \mathrm{C}$ становить від 10,9 до $15,5 \%$. Зміна режиму роботи базової ГТУ не впливатиме на частку приросту потужності низькокиплячого контуру, бо завдяки зв'язку із системою автоматичного управління ГТУ характеристики НРТ співвідносяться - 3 падінням потужності подача компримованого газу збільшуватиметься, а кількість переданої пентану теплоти не змінюватиметься.

Причиною зміни роботи і потужності турбіни на НРТ може бути не лише зміна потужності базової ГТУ, а й зміна зовнішніх умов. Було досліджено роботу ТУЕУ при зміні температури зовнішнього повітря від -20 до $+25{ }^{\circ} \mathrm{C}$ (температура суміші газів та повітря $\mathrm{t}_{\mathrm{cm}}=483$ К). Дослідження впливу зміни температури навколишнього середовища на роботу ТУЕУ проводилося згідно розроблених методики i алгоритму при зміні температури навколишнього середовища.

На рисунку 4 представлено залежність відносної потужності пентанової турбіни від потужності базової ГТУ в діапазоні температур повітря від -20 до $+25{ }^{\circ} \mathrm{C}$. За базову для порівняння взято потужність пентанової турбіни на номінальному режимі при нормальних умовах.

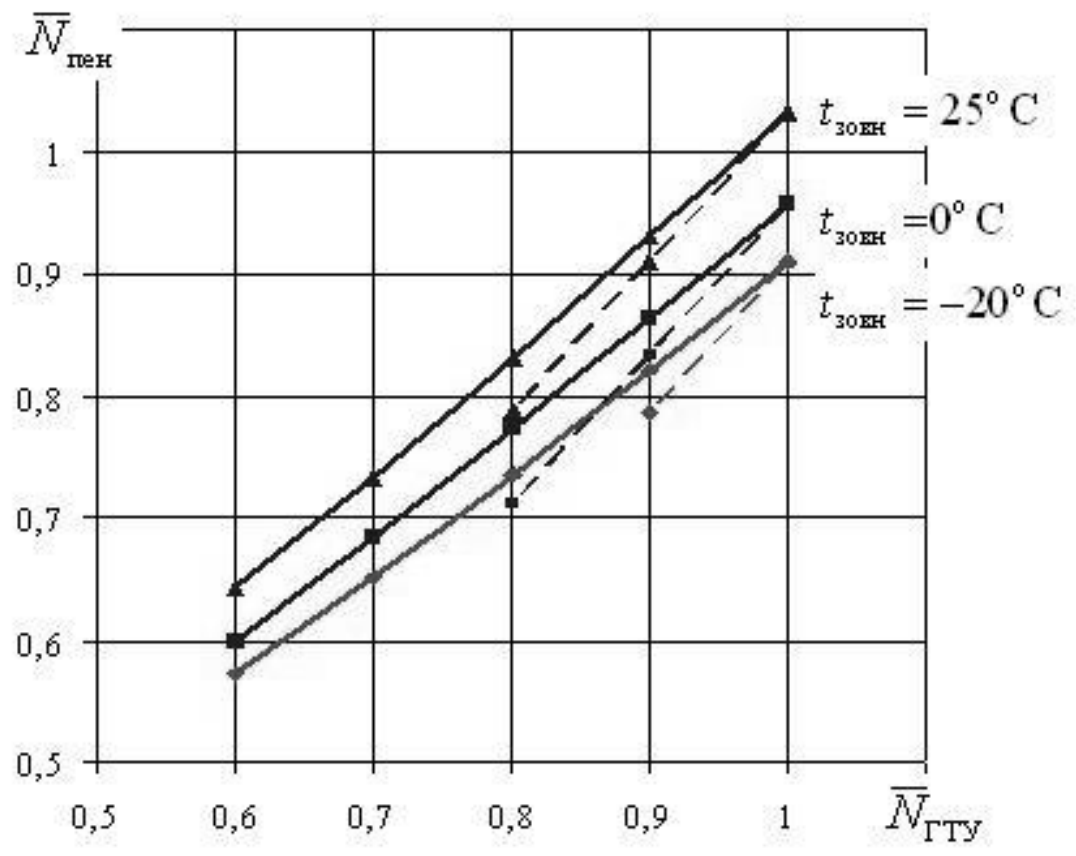

Рис. 4. Залежність відносної потужності пентанової турбіни від потужності ГТУ: - з регулюванням температури суміші повітря і вихлопних газів; - - - без регулювання початкової температури.

Результати розрахунків показують що, температура навколишнього середовища прямо пропорційно впливає на параметри пентанової турбіни: 3 iї збільшенням зростає потужність турбіни. Порівняно з випадком за відсутності стабілізації температури використання регулятора подачі повітря при зміні режиму роботи ГТУ від 0,8 номінального до номінального дає приріст потужності турбіни на пентані до 8 \%. За відсутності регулятора $\left(\mathrm{G}_{\text {пов }}=\right.$ const $)$ при режимах від 0,6 до 0,8 номінального реалізація низькокиплячого циклу Ренкіна взагалі неможлива, адже не зберігається закладений в початковій умові температурний напір в К-У, внаслідок чого не відбуватиметься генерація пари. Тому при зміні температури повітря впровадження вентилятора повітря, який оснащено системою частотного регулювання, дозволить майже вдвічі розширити експлуатаційний діапазон роботи пентанового контуру. 
Про значний вплив регульованого змішувача вихлопних газів і повітря свідчить те, що залежності $\mathrm{N}_{\text {пен }}=\mathrm{f}\left(\mathrm{t}_{\text {зовн }}\right)$ i $\mathrm{N}_{\text {гту }}=\mathrm{f}\left(\mathrm{t}_{\text {зовн }}\right) \epsilon$ протилежними, а зростання температури навколишнього середовища і пов'язане 3 цим збільшення потужності пентанової турбіни певним чином компенсує втрати потужності базової ГТУ при зростанні зовнішньої температури.

\section{ВИСНОВКИ}

1. Встановлення комплексної системи регулювання роботи ТУЕУ покращує характеристики утилізаційної установки при змінних режимах роботи ГТУ. При зменшенні потужності базової ГТУ вдвічі встановлення системи регулювання робить можливим функціонування низькокиплячого контуру при змінній температурі зовнішнього повітря в діапазоні від -20 до $+25^{\circ} \mathrm{C}$, характерному для наших широт.

2. Використання запропонованої комплексної системи регулювання початкової температури на вході в турбіну, враховуючи змінні режими роботи ГТУ та зміну зовнішньої температури, дає відносний приріст потужності пентанової турбіни на $3 \ldots 8 \%$. Її встановлення вдвічі розширює робочий діапазон початкових параметрів робочого тіла та ефективність використання скидної теплоти.

3. Зміна температури повітря суттєво впливає на потужність ГТУ, що відображається на роботі енергоустановки. При роботі ГТУ на сталому режимі потужність пентанової турбіни зі збільшенням зовнішньої температури зростає на $13 \ldots 14 \%$.

4. Додаткове встановлення в низькокиплячому контурі підігрівача пентану компримованим газом дає приріст потужності, що виробляється ТУЕУ. Відносна частка ефективної потужності ТУЕУ збільшиться на $10,9 \ldots 15,5$ \% залежно від температури НРТ на виході 3 теплообмінника. Встановлення підігрівача компримованим газом дозволить підвищити продуктивність газоперекачування на понад 5 \%, збільшуючи електричну потужність ТУЕУ на
9 \% для ГТУ простого циклу і до 17 \% для ГТУ регенеративного циклу.

\section{ЛIТЕРАТУРА}

1. Leibowitz H., Schochet D.N., Generating Electric Power From Compressor Station Resudual Heat // Pipeline and Gas Journal. - 2001. - № 11. PP. 24-26.

2. Билека Б.Д. Теплоутилизирующие энергетические и энергохолодильные установки для компрессорных станций магистральных газопроводов / Б.Д. Билека, Р.В. Сергиенко // ВосточноЕвропейский журнал передовых технологий. 2010. - № 3/2 (45). - С. 32-35.

3. Билека Б.Д. Особенности выбора начальных параметров безводного цикла Ренкина для энергетических установок, утилизирующих сбросную теплоту приводних газотурбинных установок компрессорных станций / Б.Д. Билека, В.Я. Кабков, Р.В. Сергиенко // Вестник двигателестроения. - 2011. - № 2(25)/2011. - С. 138-141.

4. Сергиенко P.B. Пути повышения эффективности рабочего цикла энергетических теплоутилизирующих установок с низкокипящими рабочими телами / Р.В. Сергиенко, Б.Д. Билека, В.Я. Кабков // Авиационно-космическая техника и технология. - 2012. - Вып. 8(95). - С. 38-42.

5. Радченко Н.И. Анализ эффективности охлаждения воздуха на входе газотурбинных двигателей в жарких климатических условиях / Н.И. Радченко, Рами Єльгерби, Рамзи Єльгерби // Газотурбинные технологии: Рыбинск, Россия. 2013. - № 4 (115). - С. 34-39.

6. Радченко Н.И. Энергоресурсосберегающая внутрицикловая тригенерация в газотурбинных установках компрессорных станций / Р.Н. Радченко, Н.И. Радченко // Авиационно-космическая техника и технология. - 2011. - № 10(87). - С. 98-103.

7. Патент України на корисну модель № 78347 // Комбінована енергетична установка для газотранспортної системи // Б.Д. Білека, Р.В. Сергієнко, заявник та власник Інститут технічної теплофізики НАН України - № u 201212143, заявл. 22.10.12, опубл. 11.03.13, Бюл. № 5. 
IMPROVING THE EFFICIENCY OF HEAT UTILIZED POWER PLANTS WITH LOW BOILING WORKING BODIES UNDER REGIMES CHANGE

\section{R.Serhiienko}

The Institute of Engineering Thermophysics of National Academy of Sciences of Ukraine, vul. Zhelyabova, 2a, Kyiv, 03680, Ukraine.

Important scientific and applied issues of selecting the operating range of heat utilized power plant (HUPP), development of ways to increase the efficiency of the plant under variable modes and changing atmospheric conditions are discussed and solved in the paper. Methods and program of thermodynamic and thermal calculation of HUPP in conditions of limited power heat source for the selected thermal difference are improved. A fundamentally new scheme of the combined power plant for the gas transmission system with controlled mixing of air, which allows to take into account the variable modes of the gas turbine plant under unstable temperature conditions of its operation is proposed.

References 7, figures 4 .

Key words: heat recovery unit, gas turbine plant, waste heat recovery, thermodynamic cycle, low-boiling working body.

1. Leibowitz H., Schochet D.N. Generating Electric Power From Compressor Station Resudual
Heat // Pipeline and Gas Journal. - 2001. - № 11. P. 24-26.

2. B.Bileka. Heat utilized and refrigerating power pants for the compressor stations of gas pipeline / B.Bileka, R.Serhiienko // Eastern-European Journal of Eenterprise Technologies. - 2010. - № 3/2 (45). - C. 32-35.

3.B.Bileka. Features of choice ofinitial parameters for waterless Rankine cycle power plants utilizing waste heat of the drive gas turbines of compressor stations / B.Bileka, V.Kabkov, R.Serhiienko // Herald of aeroenginebuilding. - 2011. - № 2(25)/2011. C. 138-141.

4. R.Serhiienko. Ways to improve the efficiency of the working cycle of heat utilized power plants with low-boiling working bodies / R.Serhiienko, B.Bileka, V.Kabkov // Aerospace technic and technology - 2012. - Вып. 8(95). - C. 38-42.

5. N.Radchenko. Analysis of cooling air efficiency at the inlet of gas turbine engines in hot climates / N.Radchenko, R.Elgebri // Gas Turbo Technology. - 2013. - № 4 (115). - C. 34-39.

6. N.Radchenko. Energy resource saving intracyclic trigeneration at gas turbine compressor stations / N.Radchenko, R.Radchenko // Aerospace technic and technology. - 2011. - № 10(87). C. 98-103.

7. Patent of Ukraine for utility model № 78347 // Combined power plant for the gas transportation system // B.Bileka, R.Serhiienko / The Institute of Engineering Thermophysics. № u 201212143, 11.03 .13 , B. № 5 . 